EETP Vol. 14, 2019, №. 1(51)

ISSN 1896-2327 / e-ISSN 2353-7787

DOI: 10.35765/eetp.2019.1451.06

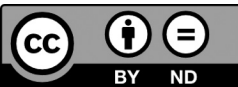

Nadesłano: 15.01.2019

Zaakceptowano: 18.03.2019

Sugerowane cytowanie: Barszcz-Skowronek J. (2019). Obowiązki domowe w świadomości dzieci w wieku przedszkolnym, "Edukacja Elementarna w Teorii i Praktyce”, vol. 14, nr 1(51), s. 83-94. DOI: 10.35765/eetp.2019.1451.06

\author{
Jolanta Barszcz-Skowronek \\ ORCID: 0000-0002-9732-0259 \\ UMCS Lublin \\ Wydział Pedagogiki i Psychologii \\ Zakład Pedagogiki Przedszkolnej
}

\title{
Obowiazki domowe w świadomości dzieci w wieku przedszkolnym
}

\section{House Chores in the Awareness of Preschool Children}

\section{SŁOWA KLUCZOWE ABSTRAKT}

uczenie się, Głównym celem artykułu jest prezentacja wyników badań dotycząobowiązki domowe, cych obowiązków domowych dzieci uczęszczających do przedszkola, dzieci, projekt $\quad$ w oparciu o rysunki dzieci wykonane w ramach aktywności dzieci edukacyjny, w warunkach domowych podczas realizacji projektu edukacyjnego samodzielność i wypowiedzi rodziców. Rodzina jako naturalna grupa odniesienia, w której ma miejsce silna identyfikacja emocjonalna, zapewnia nie tylko poczucie wspólnoty i więzi, ale także warunki do optymalnego rozwoju wszystkich jej członków. W procesie uczenia się zasadniczą rolę odgrywa kontakt psychiczny dziecka z rodzicami i działające w tym kontekście mechanizmy naśladownictwa, identyfikacji i modelowania. Dzieci powinny dbać nie tylko o swoją przestrzeń, ale i z wiekiem przejmować coraz trudniejsze obowiązki/prace domowe. Dlatego też ważne jest, aby dzieci od najmłodszych lat miały swoje obowiązki w domu. Angażowanie dziecka do obowiązków uczy je samodzielności, samodyscypliny i umiejętności efektywnego zarządzania własnym czasem. Rodzice z kolei zyskują możliwość dodatkowej interakcji z dzieckiem. Wspólne obowiązki, czyli aktywności dzieci i rodziców w warunkach domowych, są równie skuteczne w zacieśnianiu relacji wewnątrz rodziny, jak integracja poprzez zabawę. 


\section{KEYWORDS ABSTRACT}

learning, chores, The main objective of the article is to present the results of the research children, on house chores of preschool children, based on parents' utterances educational projects, and children's pictures made at home during the fulfilment of the eduindependence cational project. Family as a natural group of reference which provides the space of strong emotional identification, not only gives its members the sense of community and relation, but also the conditions for their optimum development. In the process of learning, the key role is played by the child's psychological contact with the parents and the mechanisms of imitation, identification and modelling that function within this context. Children should not only care about their space, but, as they grow older, they should take up more and more difficult obligations/chores. That is why, it is important for even the youngest children to have certain obligations at home. Making the child involved in house chores means teaching them independence, self-discipline and the ability to effectively manage their own time. Also, during the performance of the chores, the parents are given the opportunity of additional interaction with the child. Common chores, i. e. the activities of parents and children carried out at home, are as effective in improving family relations as integration through play.

\section{Wprowadzenie}

Samodzielność człowieka jest dyspozycją niezwykle istotną do podejmowania wyzwań i działań zgodnie z własną wolą. Wiąże się z gotowością do podjęcia kolejnych prób działania w celu realizacji zamierzenia, a także $z$ umiejętnością poniesienia konsekwencji własnych wyborów i decyzji. Osiągnięcia dziecka w wieku przedszkolnym w tym zakresie są podstawowym warunkiem koniecznym dla rozwoju wielu innych sfer osobowości, w tym sfery motywacji, sfery wolicjonalnej, adekwatnego obrazu własnej osoby. Samodzielność warunkuje też prawidłowe relacje społeczne dziecka. Uzyskanie samodzielności praktycznej, obejmującej różne obszary jego codziennego funkcjonowania, jest konieczne dla pomyślnej realizacji kolejnych ról społecznych i zadań rozwojowych, które stoją przed nim pod koniec edukacji przedszkolnej (Kuszak 2006).

Przygotowanie dzieci do samodzielności i odpowiedzialności w życiu dorosłym rozpoczyna się w rodzinie, w momencie pojawienia człowieka się na świecie. Właściwe postawy rodzicielskie powodują, że dziecko jest ufne wobec swoich rodziców, zwraca się do nich po rady i pomoc, jest zadowolone z rezultatów własnego wysiłku i pracy, zdolne do współdziałania z rówieśnikami oraz podejmowania zobowiązań, potrafi 
troszczyć się o własność swoją i innych. Jest pomysłowe, bystre, pewne siebie, łatwo przystosowuje się do różnych sytuacji społecznych. Przejawia dążenie do pokonywania różnych przeszkód, kończenia czynności rozpoczętych i rozwiązywania trudnych zadań, podejmowania czynności z własnej inicjatywy (Ziemska 2006).

W procesie uczenia się zasadniczą rolę odgrywa kontakt psychiczny dziecka z rodzicami i działające w tym kontekście mechanizmy naśladownictwa, identyfikacji i modelowania. „Poprzez naśladowanie dziecko uczy się od swoich rodziców znacznej części form swego zachowania, bez konieczności stosowania w rozległym zakresie metod prób i błędów po to, by móc się przekonać, jakie standardy zachowania są nagradzane w społeczności, w której żyje”. Spuścizna doświadczeń wyniesiona z domu rodzinnego ma olbrzymie znaczenie w rozwoju człowieka (Przybył 2001). „Dziecko uczestnicząc w codziennych, naturalnych sytuacjach życia rodzinnego, w bezpośrednich interakcjach między członkami rodziny, przyswaja elementarną wiedzę o świecie, wartościach, normach moralno-społecznych, kulturze domu rodzinnego, poznaje sposoby zaspokajania wielu potrzeb, rozwijania własnych zainteresowań” (Izdebska 2000). Maria Pecyna podkreśla, że więź dziecka z rodzicami uruchamia mechanizm identyfikacji, polegający na budowaniu własnego Ja pod wpływem wzoru osobowego. „Nie jest to zwykłe naśladownictwo, ale wewnętrzne przyswajanie warunków sprzyjających osiąganiu tego podobieństwa. [...] obrany za model rodzic jest jakby scenariuszem, który służy do kształtowania struktur osobowości” (1998: 37).

Ludzie zdolni są do naśladowania zachowań, które obserwowali u innych osób, w związku z tym, w wyniku obserwacji różnych działań wielu osób, możliwe jest dochodzenie do nowych, innowacyjnych rozwiązań, do samodzielnych działań twórczych. Tak więc dziecko, które może naśladować różne wzory, stykać się z różnorodnymi bodźcami, ma szansę rozwinąć własne, samodzielne działania, mimo iż wzorowane na działaniach osób z otoczenia. Tak więc rozumiane naśladowanie nie jest wiernym kopiowaniem zachowań innych, ale pozwala na stworzenie, własnych indywidualnych rozwiązań (Kuszak 2006).

\section{Podstawy terminologiczne}

Samodzielność ujmowana jest w różnych kategoriach. Behawioryści ujmują samodzielność w kategoriach nawyku. Koncepcje humanistyczne wyjaśniają ją jako dążenia podmiotowe lub jako określoną postawę życiową wobec siebie i otoczenia społecznego. Koncepcje poznawcze interpretują samodzielność jako wynik gromadzenia doświadczeń w ciągu całego życia jednostki (Kuszak 2006: 11).

Angażowanie dziecka do obowiązków uczy je samodyscypliny i umiejętności efektywnego zarządzania własnym czasem. Rodzice z kolei zyskują możliwość dodatkowej 
interakcji z dzieckiem. Wspólne obowiązki są równie skuteczne w zacieśnianiu relacji wewnątrz rodziny jak integracja poprzez zabawę.

W okresie przedszkolnym rolę wpierającą rodzinę w wychowaniu dziecka pełni przedszkole. Edukacja jest doświadczeniem społecznym, które pozwala człowiekowi sprawnie i skutecznie działać w otaczającym świecie. Człowiek uczy się za sprawą relacji z otoczeniem i aktywnie buduje wiedzę i umiejętności, nabywa kluczowe kompetencje, wzbogaca swoje stosunki z innymi ludźmi. Nauczyciel w swojej działalności edukacyjnej powinien poszukiwać takich rozwiązań metodycznych i organizacyjnych, które umożliwią dzieciom podejmowanie różnorodnej aktywności poznawczej, dzięki której w optymalny sposób będą osiągane cele edukacyjne. Dorosły może ingerować w rozwój dziecka za pomocą kilku rodzajów oddziaływań:

może tworzyć mu przestrzeń do działania,

- może podejmować działania mające na celu przyspieszenie tych zmian w rozwoju dziecka,

może zmieniać kierunek jego działania i przekształcać według nowych zasad (Brzezińska 2000: 200-202).

W opinii J. Brunera uczenie się to szukanie schematów, regularności i przewidywalności, a nauczanie równoznaczne jest z pomaganiem w kształtowaniu i odkrywaniu podobnych schematów i zasad. Nauczyciel może efektywnie wspomagać rozwój uczniów jedynie wówczas, gdy wierzy w możliwości swoich wychowanków i traktuje ich jako autonomiczne podmioty posiadające moc sprawczą. Jednym ze sposobów wykorzystania możliwości uczniów i zintensyfikowania procesu ich uczenia się jest zastosowanie metody projektów edukacyjnych (Andrzejewska 2013).

Metoda projektów jest przykładem metody pracy w aktywizującej strategii kształcenia, która charakteryzuje się największą interaktywnością, a przy tym łączy różne sposoby i techniki uczenia się. Najważniejszą przesłanką jest kształtowanie aktywnej postawy badacza wobec otoczenia, uczenie samodzielności w myśleniu i rozwiązywaniu problemów oraz rozwijanie zainteresowań ucznia. Pozwala na wybór aktywności dzieciom w zależności od poziomu rozwoju, pobudza do myślenia, uczy zastosowania nowo nabytej wiedzy w praktyce oraz dzielenia się informacjami z innymi, kształtując tym samym kompetencje komunikacyjne i społeczne. Metoda projektów umożliwia naukę poprzez działanie, bezpośrednie polisensoryczne doświadczanie, co podnosi poziom efektywności kształcenia dzieci. „Projekt stanowi swoisty «kręgosłup» doświadczeń edukacyjnych uczniów i nauczycieli. U ich podstaw leży głębokie przekonanie, że uczenie się poprzez działanie ma wielką wartość, a dyskusje w grupie oraz powrót do wcześniejszych pomysłów i doświadczeń to najlepszy sposób na zdobywanie i poszerzanie wiedzy" (Helm, Katz 2003: 29). 


\section{Założenia badawcze}

Podstawą do przeprowadzenia badań były doświadczenia edukacyjne zgromadzone w projektach edukacyjnych realizowanych w Przedszkolu $\mathrm{nr} 1 \mathrm{w}$ Bełżycach w latach 2014-2018. Zasadą wyboru tematów do realizacji projektów był namysł członków rady pedagogicznej związany z planem pracy przedszkola czy też z ważnymi wydarzeniami w środowisku lokalnym czy w kraju.

W roku szkolnym 2017/2018 w Przedszkolu nr 1 realizowane były trzy dwutygodniowe projekty edukacyjne: „Parasol, czyli zrównoważony rozwój”, „Moje miasto Bełżyce - 600 lat”, oraz „Świadomy przedszkolak dziś - świadomy obywatel jutro”.

Celem ostatniego projektu było:

- wspieranie wielokierunkowej aktywności dziecka w przedszkolu i w domu,

- tworzenie sytuacji sprzyjających rozwojowi nawyków i zachowań prowadzących do samodzielności i dbania o zdrowie,

- współpraca z rodzicami i innymi podmiotami na rzecz tworzenia warunków umożliwiających rozwój tożsamości dziecka.

Ponadto zwrócono uwagę na wypełnianie przez dzieci w projekcie obowiązków związanych z wykonywaniem zadań domowych, które były egzemplifikacją treści projektowanych realizowanych $\mathrm{w}$ przedszkolu. Tematyka trzeciego dnia projektu: „Dziewczynki i chłopcy równi w swoich prawach” nawiązywała do szeroko pojętego partnerstwa, w tym partnerstwa w przyjmowaniu i wykonywaniu obowiązków domowych w rodzinie. Tabela 1 . ukazuje działania podejmowane w ramach realizacji projektu edukacyjnego „Świadomy przedszkolak dziś - świadomy obywatel jutro” oraz rodzaje zadań domowych dzieci skorelowanych z projektem.

Tabela nr 1 . Tematy dnia i zadania projektu

\begin{tabular}{|c|c|}
\hline Temat dnia projektowego & Praca/aktywność domowa na ten dzień \\
\hline Być darczyńcą & Podziel się książką/zabawką \\
\hline Po co się uczymy? & $\begin{array}{c}\text { Przynieś akcesoria do wykonywania różnych } \\
\text { zawodów }\end{array}$ \\
\hline $\begin{array}{c}\text { Dziewczynki i chłopcy równi w swoich } \\
\text { prawach }\end{array}$ & Narysuj swoje obowiązki domowe \\
\hline Rodzi się dziecko. I co dalej? & Przynieś swoje zdjęcia z niemowlęctwa \\
\hline Ziemia - planeta życia & $\begin{array}{c}\text { Przynieś książki o Ziemi, człowieku, nauce. } \\
\text { Dowiedz się, co to jest smog? }\end{array}$ \\
\hline Skarby Ziemi & Przynieś jakiś skarb Ziemi \\
\hline
\end{tabular}




\section{EETP 51 .}

\begin{tabular}{|c|c|}
\hline Temat dnia projektowego & Praca/aktywność domowa na ten dzień \\
\hline Bezpieczeństwo & Dowiedz się, kto dba o bezpieczeństwo \\
\hline W zdrowym ciele zdrowy duch & Przyjdź do przedszkola w stroju sportowym \\
\hline Woda & Przynieś swoją ulubioną wodę mineralną \\
\hline Dzieci świata - korowód & Przygotuj z rodzicami strój (dzieci świata) \\
\hline
\end{tabular}

\section{Problematyka badawcza}

W czasie projektu edukacyjnego dzieci wypracowują wiele materiałów, które z założenia są wykorzystywane jako materiał badawczy. Są to m.in.: mapy kategorialne, dzienniczki badacza, kąciki badacza, prace domowe, prace plastyczne i inne wytwory działalności dzieci.

Inspiracją do podjęcia badań nad obowiązkami domowymi dzieci był komunikat z badań przeprowadzonych przez CBOS (CBOS 2018) „Kobiety i mężczyźni w domu”, z którego jednoznacznie wynika, że obowiązki domowe wciąż prawie wyłącznie przynależą do kobiet.

Główny problem badań to pytanie o to, jaka jest świadomość dzieci na temat ich obowiązków wykonywanych w domu rodzinnym? W badaniach wykorzystano wytwory prac dzieci - pracę plastyczną „Moje obowiązki domowe”.

Do Przedszkola nr 1 w Bełżycach w roku szkolnym 2017/2018 uczęszczało 200 dzieci w wieku od 3 do 5 lat. Analizie badawczej poddałam 124 prace. Tyle dzieci okazało aktywność w warunkach domowych, polegającą na wykonaniu rysunku (na 176 obecnych dzieci będących w tym dniu w przedszkolu). Jedna praca nie została uwzględniona w analizie ze względu na brak możliwości interpretacji (poziom bazgroty). W pracach jedno dziecko ilustrowało jeden lub kilka swoich obowiązków domowych.

Liczba prac analizowanych w poszczególnych grupach wiekowych:

dzieci 3-letnie - $47(37,9 \%)$

- dzieci 4-letnie - $30(24,2 \%)$

- dzieci 5-letnie - $47(37,9 \%)$

Po analizie prac wyodrębniono następujące kategorie obowiązków:

1. porządki domowe (ścieranie kurzu, zamiatanie, mycie naczyń, podlewanie kwiatów, wieszanie prania);

2. dbanie o własną przestrzeń i własność (sprzątanie zabawek, ścielenie łóżka, układanie ubrań); 
3. czynności z wykorzystaniem urządzeń AGD (zmywarka, odkurzacz, pralka) wkładanie naczyń, segregowanie i wkładanie ubrań, dodawanie proszku, soli, kapsułek, nabłyszczacza, odkurzanie, włączanie urządzeń;

4. opieka nad zwierzętami (psy, koty, króliki, rybki, chomiki, kury, papugi) sprzątanie, karmienie, wychodzenie na spacer;

5. prace kuchenne (przygotowywanie posiłków, nakrywanie i sprzątanie stołu);

6. prace w ogrodzie (podlewanie roślin, zbieranie skoszonej trawy, wyrywanie chwastów, koszenie trawy z tatą, jeżdżenie traktorem w pole);

7. samoobsługa (mycie, jedzenie, ubieranie);

8. zakupy (udział, planowanie);

9. chodzenie do przedszkola;

10. zabawa;

11. opieka nad rodzeństwem.

\section{Opis i analiza badań własnych}

Tabela 1. Kategorie obowiązków domowych w badanej grupie dzieci

\begin{tabular}{|c|c|c|c|c|c|c|c|c|}
\hline \multirow{2}{*}{$\begin{array}{l}\text { Kategoria } \\
\text { obowiązków } \\
\text { domowych }\end{array}$} & \multicolumn{8}{|c|}{ Liczba obowiązków } \\
\hline & $\begin{array}{l}\text { Dzieci } \\
\text { trzy- } \\
\text { 'letnie }\end{array}$ & $\%$ & $\begin{array}{l}\text { Dzieci } \\
\text { cztero- } \\
\text { letnie }\end{array}$ & $\%$ & $\begin{array}{l}\text { Dzieci } \\
\text { pięcio- } \\
\text { letnie }\end{array}$ & $\%$ & Razem & $\%$ \\
\hline porządki domowe & 35 & 74 & 28 & 93 & 47 & 100 & 109 & 88 \\
\hline $\begin{array}{c}\text { dbanie o swoją } \\
\text { przestrzeń, własność }\end{array}$ & 33 & 70 & 21 & 70 & 46 & 98 & 100 & 81 \\
\hline $\begin{array}{c}\text { czynności } \\
\text { z wykorzystaniem } \\
\text { urządzeń }\end{array}$ & 11 & 23 & 20 & 67 & 43 & 91 & 74 & 60 \\
\hline opieka nad zwierzętami & 5 & 11 & 12 & 40 & 23 & 49 & 40 & 32 \\
\hline prace kuchenne & 7 & 15 & 7 & 23 & 16 & 34 & 30 & 24 \\
\hline prace w ogrodzie & 3 & 6 & 5 & 17 & 19 & 40 & 27 & 22 \\
\hline samoobsługa & 14 & 30 & 7 & 23 & 5 & 11 & 26 & 21 \\
\hline zakupy & 2 & 4 & 4 & 13 & 15 & 32 & 21 & 17 \\
\hline chodzenie do przedszkola & 1 & 2 & 4 & 13 & 10 & 21 & 15 & 12 \\
\hline opieka nad rodzeństwem & 1 & 2 & 2 & 7 & 6 & 13 & 9 & 7 \\
\hline
\end{tabular}

Źródło: opracowanie własne. 
Analiza zaprezentowanych wyników wskazuje, że najczęstsze kategorie obowiązków domowych, w których uczestniczyły badane dzieci to porządki domowe (88\%), dbanie o swoją przestrzeń i własność (81\%) a także czynności związane z wykorzystaniem urządzeń AGD - (60\%). Obowiązi związane z opieką nad zwierzętami przyjmuje $32 \%$ badanych dzieci. Spora grupa badanych dzieci pomaga w kuchni $(24 \%)$ czy też w ogrodzie (22\%). Udział dzieci w wykonywaniu tych prac zwiększa się wraz $\mathrm{z}$ wiekiem dziecka.

17\% uczestniczy w zakupach domowych zarówno na etapie planowania, jak i samych zakupów. W badanej grupie udział dzieci 3-letnich jest najmniejszy, a zwiększa się wraz z wiekiem dziecka.

Chodzenie do przedszkola (12\%) jako obowiązek wzrasta wraz z wiekiem dzieci i jest najczęstsze u dzieci 5-letnich.

9 dzieci $(7 \%)$ podejmuje obowiązek pomocy w opiece nad rodzeństwem. I tu, obowiązek ten zależny jest od wieku dziecka: im młodsze dziecko, tym mniejszy udział w obowiązku.

Analiza obowiązków dzieci w zakresie samoobsługi (21\%) wskazuje, że jest to zadanie dla 30\% badanych dzieci 3-letnich, 23\% dzieci 4-letnich i 11\% dzieci 5-letnich, co może oznaczać, że czynności samoobsługowe są bardziej istotne u dzieci młodszych i są wskazywane jako obowiązek przez dorosłych (umiejętność mycia się, ubierania czy samodzielnego jedzenia). W miarę rozwoju dziecka wzrasta jego samodzielność w zakresie samoobsługi i nie jest to już postrzegane jako obowiązek, lecz nawyk.

U 10\% dzieci pojawia się zabawa traktowana jako „obowiązek”. Być może to działania określane jako „uczenie się przez zabawę” mają związek z takim spostrzeganiem zabawy, która nie ma nic wspólnego z zabawą swobodną podejmowaną przez dziecko.

Tabela 2. Liczba przyjętych obowiązków a wiek dzieci (działania dzieci uświadomione jako obowiązek)

\begin{tabular}{|c|c|c|c|c|c|c|}
\hline \multirow{2}{*}{ Liczba obowiązków } & \multicolumn{5}{|c|}{ Wiek dzieci } \\
\cline { 2 - 7 } & \multicolumn{2}{|c|}{ 3-letnie } & \multicolumn{2}{c|}{ 4-letnie } & \multicolumn{2}{c|}{ 5-letnie } \\
\cline { 2 - 7 } & Liczba & $\%$ & Liczba & $\%$ & Liczba & $\%$ \\
\hline 1 & 31 & 66 & 10 & 33 & 8 & 17 \\
\hline 2 & 8 & 17 & 11 & 37 & 14 & 30 \\
\hline 3 & 7 & 15 & 7 & 23 & 19 & 40 \\
\hline 4 i więcej & 0 & - & 2 & 7 & 5 & 11 \\
\hline
\end{tabular}

Źródło: opracowanie własne 
W pracach jedno dziecko rysowało jeden lub kilka swoich obowiązków domowych. W związku z powyższym dokonałam analizy pod kątem liczby obowiązków przyjmowanych przez badane dzieci ze względu na wiek.

Z analizy materiału badawczego ujętego w tabeli nr 2, wynika, że świadomość przyjętych obowiązków u dzieci 3-letnich jest najmniejsza a wzrasta wraz z wiekiem dzieci.

Podczas realizacji projektu „Świadomy przedszkolak dziś - świadomy obywatel jutro", dzieci przez okres 2 tygodni wykonały 10 prac domowych, traktowanych przez nauczycieli jako obowiązki domowe, a wykonanych w partnerstwie z domem rodzinnym. Czynnikiem warunkującym partnerstwo jest działanie. Poprzez działanie partnerzy osiągają swoisty kształt wzajemnych relacji, jakim jest partnerstwo. Owo działanie jest nacechowane w sposób szczególny. W każdym ujęciu partnerstwa jest ono współdziałaniem (Mendel 2000). Przedszkole w porozumieniu i współpracy z rodziną dziecka ma wychowywać, ukazując potrzeby duchowe człowieka, rozwijać psychiczne i fizyczne możliwości oraz formułować podstawę kształcenia ogólnego tak, by dzieci stawały się pełnowartościowymi, odpowiedzialnymi i niezależnymi osobami w życiu prywatnym i społecznym. (Bałachowicz 2015: 14-15). Dziecko w wieku przedszkolnym do wykonania większości obowiązków potrzebuje wsparcia dorosłych, aby mogło wywiązać się ze swoich zadań. Aktywność dziecka w środowisku domowym dla dzieci w projekcie jest jednocześnie zadaniami dla rodziców. W tabeli nr 3 przedstawione są dane ukazujące liczbę zadań wykonanych przez dzieci, przy wsparciu dorosłych.

Tabela 3. Prace domowe dzieci w projekcie traktowane jako obowiązki domowe wykonywane $\mathrm{w}$ partnerstwie z domem rodzinnym - ranking.

\begin{tabular}{|c|c|c|c|c|}
\hline Lp. & Rodzaje aktywności/zadania projektowe & $\begin{array}{c}\text { Frekwencja } \\
\text { dzieci } \\
\text { w przedszkolu }\end{array}$ & $\begin{array}{c}\text { Ilość } \\
\text { wykonanych } \\
\text { zadań } \\
\text { domowych }\end{array}$ & $\%$ \\
\hline 1. & Przygotuj z rodzicami strój (dzieci świata) & 155 & 155 & 100 \\
\hline 2. & Przynieś jakiś skarb Ziemi & 164 & 160 & 98 \\
\hline 3. & Przyjdź do przedszkola w stroju sportowym & 159 & 147 & 93 \\
\hline 4. & $\begin{array}{l}\text { Wykonaj w domu lub przynieś z domu, } \\
\text { akcesoria do utworzenia kącików badawczych } \\
\text { do wykonywania różnych zawodów }\end{array}$ & 177 & 151 & 85 \\
\hline 5. & Przynieś swoje zdjęcia z niemowlęctwa & 183 & 144 & 79 \\
\hline 6. & $\begin{array}{l}\text { Przynieś z domu lub wypożycz z biblioteki } \\
\text { książki o Ziemi, nauce, człowieku }\end{array}$ & 180 & 134 & 74 \\
\hline
\end{tabular}




\begin{tabular}{|c|c|c|c|c|}
\hline Lp. & Rodzaje aktywności/zadania projektowe & $\begin{array}{c}\text { Frekwencja } \\
\text { dzieci } \\
\text { w przedszkolu }\end{array}$ & $\begin{array}{c}\text { Ilość } \\
\text { wykonanych } \\
\text { zadań } \\
\text { domowych }\end{array}$ & $\%$ \\
\hline 7. & $\begin{array}{c}\text { Narysuj swoje obowiązki domowe. Dowiedz się, } \\
\text { jakie obowiązki mają inne osoby w domu }\end{array}$ & 176 & 124 & 71 \\
\hline 8. & Dowiedz się, kto dba o bezpieczeństwo & 155 & 91 & 59 \\
\hline 8. & $\begin{array}{c}\text { Przynieś do przedszkola książkę lub zabawkę, } \\
\text { którą obdarujesz inne dziecko }\end{array}$ & 172 & 102 & 59 \\
\hline 10. & Przynieś swoją ulubioną wodę mineralną & 156 & 87 & 56 \\
\hline
\end{tabular}

Źródło: opracowanie własne

Przez wszystkich została wykonana praca domowa, której celem było wykonanie stroju, w którym dzieci przemaszerowały przez miasto w barwnym korowodzie. Praca ta była ostatnim zadaniem w trwającym dwa tygodnie projekcie.

$\mathrm{Na}$ drugim miejscu (98\%) uplasowało się zadanie projektowe związane z bogactwami naturalnymi Ziemi. Wśród rzeczy przyniesionych przez dzieci znalazły się: kamienie, muszelki, patyczki, kora, owoce, warzywa, piasek, węgiel, kwiaty, itp. Przygotowanie i przyniesienie do przedszkola stroju sportowego znalazło się na trzecim miejscu (93\%). Wszystkie dzieci uczestniczyły w zabawach ruchowych na stadionie miejskim. Zadanie polegające na przyniesieniu wykonanych $\mathrm{w}$ domu samodzielnie lub z rodzicami akcesoriów, lub też rzeczywistych atrybutów różnych zawodów, osiągnęło czwarty wynik - 85\%. Na piątym miejscu znalazło się zadanie projektowe z czwartego dnia projektu. Dzieci miały wyszukać i przynieść swoje zdjęcie z okresu niemowlęctwa. Zadanie wykonało $79 \%$ obecnych w przedszkolu tego dnia dzieci.

$\mathrm{Na}$ piąty dzień dzieci miały za zadanie przynieść do przedszkola książki o Ziemi, nauce, człowieku i dowiedzieć się od dorosłych lub wspólnie z nimi wyszukać informacje nt. smogu. To zadanie zajęło szóstą pozycję - 74\%. Większość dzieci przyniosła książki z domowych bibliotek, jednak były też dzieci, które miały książki z biblioteki miejskiej. Nie dysponuję danymi, ile dzieci uzyskało informacje na temat smogu. Siódme miejsce to rysunki przedstawiające obowiązki domowe wykonywane przez dzieci w domu, a będące tematem rozważań niniejszego artykułu - wykonało je 71\% obecnych w tym dniu dzieci. Oprócz tego dzieci w rozmowach z całą grupą wskazywały obowiązki, jakie wykonują inni domownicy.

Na kolejnym, ósmym miejscu jest zadanie, którego wykonanie wiązało się z obdarowaniem innego dziecka zabawką lub książką (59\%). Taki sam wynik uzyskała praca „Porozmawiaj z dorosłymi nt. bezpieczeństwa. Kto dba o bezpieczeństwo?”. Dzieci 
w rozmowie z całą grupą dzieliły się wiedzą i wskazywały osobę, z którą rozmawiały nt. bezpieczeństwa. Zadaniem do wykonania na dziewiąty dzień projektu, było przyniesienie ulubionej wody mineralnej. Zadanie to wykonało $56 \%$ obecnych w tym dniu dzieci, co wskazuje, że było to zadanie, które zostało wykonane przez najmniejszą liczbę dzieci.

Wykonywanie zadań projektowych przez dzieci we współpracy z rodzicami, w analizowanym projekcie edukacyjnym: „Świadomy przedszkolak dziś - świadomy obywatel jutro", wyniosło od 56\% do 100\%. Na podstawie tych danych można stwierdzić, że rodzice są $\mathrm{w}$ różnym stopniu zaangażowani $\mathrm{w}$ pomoc dzieciom $\mathrm{w}$ wykonywaniu przez nie obowiązków i pełnią rolę wspierająca, tym samym podtrzymując ideę partnerstwa w edukacji swoich dzieci.

\section{Podsumowanie}

Przedstawione przeze mnie wyniki analiz wskazują, że obowiązki domowe, często pojedyncze, mają już dzieci trzyletnie. Wraz z wiekiem dziecka zwiększa się ilość obowiązków, a także ich zakres. Oprócz prostych prac porządkowych, dzieci podejmują się pomocy w nakrywaniu do stołu, opiece nad zwierzętami czy też opiece nad rodzeństwem. Wypełniając rozmaite zadania, uczą się brania odpowiedzialności za zajmowaną przestrzeń oraz kształtują w sobie poczucie sprawstwa, dostrzegając konsekwencje podejmowanych zachowań. Kolejnym pozytywnym aspektem podejmowania aktywności w zakresie wykonywania prac domowych jest nauka kontrolowania czasu oraz planowania własnych zadań.

Stawianie dzieciom jasnych wymagań i angażowanie ich w pomoc domową już od najmłodszych lat przynosi wiele pozytywnych efektów. Widoczne są one zwłaszcza w późniejszym życiu. Jako ludzie dorośli osiągają liczne sukcesy w rozmaitych obszarach, nie tylko tych związanych ze sferą naukową i zawodową, lecz także z codziennym funkcjonowaniem i nawiązywaniem relacji. Zdaniem Martina Rossmanna: „Poprzez uczestnictwo w pracach domowych, rodzice uczą dzieci odpowiedzialności, uczestniczenia w rodzinnym życiu, poczucia empatii oraz dbania o siebie”. Angażowanie małych dzieci w prace domowe niesie ze sobą ryzyko wydłużenia czasu pracy czy konieczności wykonania dodatkowych porządków, gdy np. pomaga ono w kuchni. Mając na uwadze perspektywę wspierania rozwoju dziecka, warto podjąć ten wysiłek.

Potwierdzenie wyników badań znaleźć można między innymi w koncepcji Rossmanna. Przez ponad dwadzieścia lat zbierał on dane od 84 osób, dokonując pomiaru w trzech fazach życia - u dzieci trzy- i czteroletnich, następnie u dziewięcio- i dziesięciolatków oraz u piętnasto- i szesnastolatków. Wyniki badań wykazały, że młodzi dorośli, którzy już w wieku trzech lub czterech lat angażowali się w wypełnianie 
obowiązków domowych, osiągali większe sukcesy w dorosłym życiu. Warto nadmienić, że efektu tego nie zaobserwowano w przypadku dzieci, które obowiązki zaczęły wypełniać w starszym wieku, na przykład będąc już nastolatkami (Hajdas 2018).

\section{Bibliografia}

Andrzejewska J. (2013). Metoda projektów szansa intensyfikacji uczenia się uczniów z klas I-III, „Roczniki Pedagogiczne”, t. 5(41), nr 2.

Bałachowicz J. (2017). Edukacja wczesnoszkolna w procesie zmiany. Dyskurs standardów czy dyskurs wartości? „Lubelski Rocznik Pedagogiczny”, z. 1.

Brzezińska A. (2000), Spoteczna psychologia rozwoju, Warszawa: Wydawnictwo Naukowe "Scholar".

Hajdas S. (2018). Obowiązki domowe. Dręczenie dzieci czy troska o ich doroste życie <https:// smartstart.pl/sabina-hajdas-obowiazki-domowe-dreczenie-dzieci-czy-troska-o-ich-dorosle-zycie> [dostęp: 13.01.2019].

Helm J.H., Katz L.G. (2003). Mali badacze - metoda projektu w edukacji elementarnej, tłum. E. Pulkowska, Warszawa: Wyd. CODN.

Izdebska J. (2000). Dziecko w rodzinie u progu XXI wieku, Białystok: Trans Humana.

Kuszak K. (2006). Dynamika rozwoju samodzielności dziecka w wieku przedszkolnym, Toruń: UAM.

Mendel M. (2000). Partnerstwo rodzin szkoty i gminy, Toruń: Wydawnictwo A. Marszałek.

Pecyna M. (1998). Rodzinne uwarunkowania zachowania dziecka w świetle psychologii klinicznej, Warszawa: WSiP.

Przybył I. (2001). Źródta wiedzy o rolach matżeńskich, „Roczniki Socjologii Rodziny”, t. XIII.

Ziemska M. (2009). Postawy rodzicielskie, Warszawa: Wiedza Powszechna.

\section{Źródła internetowe:}

CBOS (2018). Kobiety i mężczyźni $w$ domu. Komunikat z badań, nr 127, <https://www. cbos.pl/SPISKOM.POL/2018/K_127_18.PDF>[dostęp13.01.2018].

\section{ADRES DO KORESPONDENCJI}

Mgr Jolanta Barszcz-Skowronek

Wydział Pedagogiki i Psychologii

Zakład Pedagogiki Przedszkolnej

UMCS Lublin

e-mail: jolbs@interia.pl 